\title{
Малогабаритные узкополосные лазеры для распределенных волоконно-оптических датчиков
}

\author{
Д.Р. Харасов ${ }^{1,2, *}$, $\underline{\text { Э.А. Фомиряков }}^{1,3}$, О.Е. Наний ${ }^{1,3}$, С.П. Никитин ${ }^{1}$, В.Н. Трещиков ${ }^{1}$ \\ ${ }^{l}$ ООО «Т8 Сенсор», г. Москва \\ ${ }^{2}$ Московский физико-технический институт, г. Долгопурдный \\ ${ }^{3}$ МГУ им. М. В. Ломоносова, Физический факультет, г. Москва \\ *E-mail: kharasov@phystech.ru
}

DOI: 10.31868/RFL2020.139-140

Высокостабильные узкополосные лазеры востребованы как в научных исследованиях, так и в актуальных приложениях таких, как волоконнооптические системы передачи, интерферометрия, когерентная рефлектометрия [1-3], радиофотоника и др. Кроме низкого уровня фазовых и амплитудных шумов излучения лазера для таких применений особенно важны компактность, мобильность, технологичность и малая стоимость с различными методами снижения фазового шума: диодный лазер с внешним кристаллическим резонатором с модами шепчущей галереи (МШГ) $[4,5]$ (на примере лазеров ОЕ Waves и совместных исследований Российского квантового центра (РКЦ) и Т8), диодный лазер с внешней планарной брэгговской решеткой (БР) [6] (на примере лазера RIO Orion) и одночастотный волоконный POC-лазер (на примере лазера EFL-SF-1550 компании «Инверсия-Файбер»).

Ранее [7] с помощью метода гетеродинирования были измерены ширины линий и уходы частоты в ряде лазеров. В этой работе предыдущие результаты дополнены измерениями с помощью метода самогетеродирования с линией задержки 100 км [8,9], позволяющего провести измерения уровней белого и фликкер-шумов частоты [10] без использования реперного лазера. Экспериментальные результаты измерений среднеквадратичного отклонения (СКО) Алана частоты, подтвержденные численным анализом выходного сигнала интерферометра на основе модельного белого и фликкер-шумов [11], приведены на рис.1.

Результаты обработки данных обобщены в таблице 1. Среди протестированных лазеров наименьшими фазовыми шумами обладает лазер ОЕ Waves, однако применение такого типа лазеров затруднено при наличии сильных внешних вибраций, нарушающих режим затягивания моды лазера резонатором с МШГ. Схожие характеристики демонстрируют лазеры с МШГ-резонатором, разрабатываемые в РКЦ. Очень узкой линией (менее 100 Гц) обладает лазер «Инверсии-файбер», но при этом у него на порядок выше уровень фликкер-шума, чем у лазеров на МШГ. Лазер RIO Orion обладает как минимум на порядок большей мновенной шириной линии ( 2 кГц), чем лазеры OE Waves и «Инверсии-файбер», и примерно таким же уровнем фликкер-шума, как у лазера «Инверсии-файбер». Главным преимуществом лазера RIO Orion является слабая чувствительность к внешним вибрациям и изменениям температуры [5], что позволяет использовать его в оптических датчиках для реальных (полевых) применений. Так как фликкер-шум частоты в лазерах обычно связан с техническими факторами, разработка методов подавления фликкер-шума частоты [12-14] является важной практической задачей.

Итак, в работе приведены результаты измерений фазовых шумов в малогабаритных лазерах с низкими уровнями фазового шума для широкого диапазона прикладных задач. 


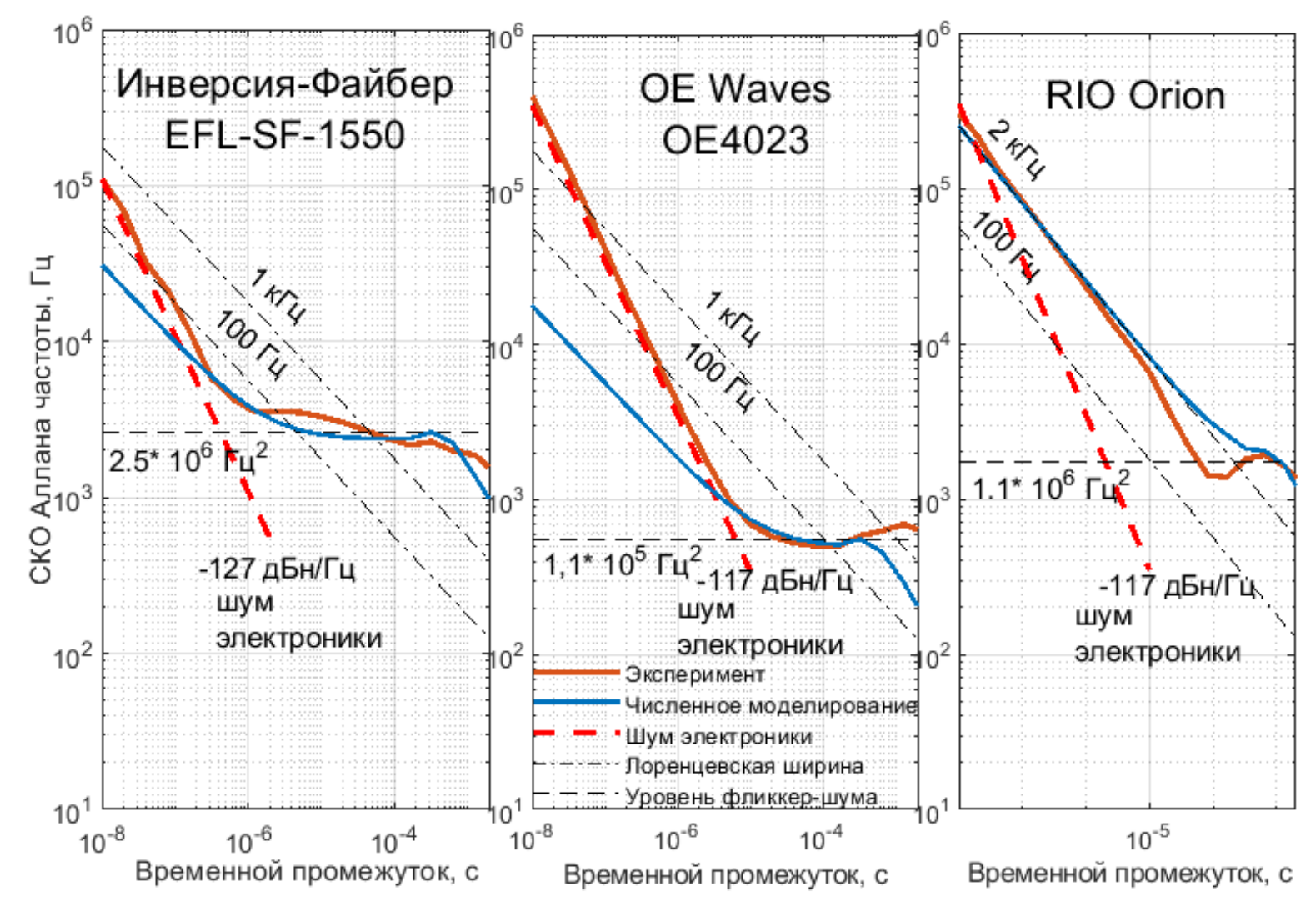

Рис.1 Эксперимент и численное моделирование СКО Аллана частоты биений на выходе неравноплечного интерферометра Маха - Цендера с линией задержки 100 км

Таблица 1. Результаты измерений лазеров

\begin{tabular}{|c|c|c|c|c|}
\hline Лазер & $\begin{array}{c}\text { Метод достижения } \\
\text { узкой линии }\end{array}$ & $\begin{array}{c}\text { Мгновенная } \\
\text { ширина } \\
\text { линии, кГц }\end{array}$ & $\begin{array}{c}\text { Уровень } \\
\text { фликкер-шума, } \\
\Gamma^{2}\end{array}$ & $\begin{array}{c}\text { Уход } \\
\text { частоты } \\
\text { [7], МГц/с }\end{array}$ \\
\hline OE Waves OE4023 & МШГ-резонатор & $<0,1$ & $10^{5}$ & $<1$ \\
\hline RIO Orion & Планарная БР & 2 & $10^{6}$ & - \\
\hline «Иверсия-файбер» & Волокно с БР & $<0,1$ & $2,510^{6}$ & $<0,25$ \\
\hline
\end{tabular}

\section{Литература}

[1] S.V. Shatalin, V. N. Treschikov \& A. J. Rogers, Applied optics, 37(24), 5600-5604 (1998)

[2] S.P. Nikitin, A.I. Kuzmenkov et al, Laser Physics, 28(8), 085107 (2018)

[3] S.P. Nikitin, P.I. Ulanovskiy et al, Laser Physics, 26(10), 105106 (2016)

[4] W. Liang et al., Nature communications 6.1, 1-6 (2015)

[5] N. M. Kondratiev et al., Optics Express 25.23 (2017): 28167-28178

[6] M. Alalusi et al., Fiber Optic Sensors and Applications VI. International Society for Optics and Photonics (2009)

[7] S.P. Nikitin, E.A. Fomiryakov et al, J. Lightwave Technology 38, 1446-1453 (2020)

[8] L. Richter et al., IEEE Journal of Quantum Electronics 22.11, 2070-2074 (1986)

[9] L. B. Mercer, J. Lightwave Technology 9.4, 485-493 (1991)

[10] Ф. Риле, Стандарты частоты. Принциипы и приложения. ФИЗМАТ-ЛИТ, 2009

[11] J. N. Kasdin, Proceedings of the IEEE 83.5, 802-827 (1995)

[12] Drever, R. W. P., et al. Applied Physics B 31.2, 97-105 (1983)

[13] M. Poulin et al. Laser Resonators and Beam Control XII. Vol. 7579. International Society for Optics and Photonics (2010)

[14] E. Kirilov et al. Applied Physics B 119.2, 233-240 (2015) 